Paideusis

\title{
A New Glass Bead Game: Redesigning the Academy
}

\section{Don Nelson}

Volume 17, Number 2, 2008

URI: https://id.erudit.org/iderudit/1072429ar

DOI: https://doi.org/10.7202/1072429ar

See table of contents

Publisher(s)

Canadian Philosophy of Education Society

ISSN

0838-4517 (print)

1916-0348 (digital)

Explore this journal

Cite this article

Nelson, D. (2008). A New Glass Bead Game: Redesigning the Academy. Paideusis, 17(2), 39-49. https://doi.org/10.7202/1072429ar

\section{Article abstract}

The academy has gained a reputation as a place of authoritative statements, truth, and insight as a result of its long history. Yet during that history its authority to make definitive statements has been built on different foundations-now overlapped and layered. Each source of authority has buried, overlaid, or sometimes supplanted the previous one while the institution has carried on. Is this historical value still solid or is it threatened by the conditions we find ourselves in today? As members of the academy, perhaps we need to ask ourselves about the foundations on which we build and the functions that the Academy may yet serve in society. Using thoughts inspired by Herman Hess's Magister Ludi, this paper explores those questions.
This document is protected by copyright law. Use of the services of Erudit (including reproduction) is subject to its terms and conditions, which can be viewed online.

https://apropos.erudit.org/en/users/policy-on-use/ 


\title{
A New Glass Bead Game: Redesigning the Academy
}

DON NELSON

Simon Fraser University, Canada

\begin{abstract}
The academy has gained a reputation as a place of authoritative statements, truth, and insight as a result of its long bistory. Yet during that bistory its authority to make definitive statements bas been built on different foundationsnow overlapped and layered. Each source of authority has buried, overlaid, or sometimes supplanted the previous one while the institution has carried on. Is this historical value still solid or is it threatened by the conditions we find ourselves in today? As members of the academy, perhaps we need to ask ourselves about the foundations on which we build and the functions that the Academy may yet serve in society. Using thoughts inspired by Herman Hess's Magister Ludi, this paper explores those questions.
\end{abstract}

\section{Introduction}

Spending so much time learning and at work in the Academy, I have to occasionally wonder "What for?" Increasingly, the reason to seek an education is captured in a neologism-credentialing. One seeks an academic credential to qualify for a job, to raise one's income, or to seek the respect that may still come with a degree - at least in the minds of many of the students that I work with in secondary school. The idea of seeking a post-secondary education for its own sake, or for virtues other than monetary or social that it might bestow, is almost entirely foreign. As it is for these students, so it is with society as a whole. And if it is so for the Academy as a whole, it may be especially so for the formerly dominant "traditional culture of the humanities."

The philosophy of education comprises one portion of that culture. As a philosopher of education, I hope that as a result of work and study, I might have something of value to say to the whole community of educators. Yet often what philosophers have to say, especially when counter to, or critical of, prevailing discourse is ignored or discounted. Like many academics, the main audience for the work of philosophers of education is other philosophers while, practitioners have little interest in the work. Not only has the philosophy of education had little impact on the politics of schoolingthose largely being set out along ideological grounds by people with little study in philosophy or education-but many teachers remember courses in the theory and philosophy of education as being of little relevance to their work. ${ }^{2}$ Why should this be?

The reasons for the perception of the philosophy of education as being on the sidelines of

1 As C. P. Snow (1998) called it.

${ }^{2}$ Not that this is an entirely new concern. See Harold Entwistle, "The Relationship between Educational Theory and Practice: A New Look" and Elana Joram, "Clashing epistemologies: Aspiring teachers', practicing teachers', and professors' beliefs about knowledge and research in education."

(C) Copyright 2008. The author, Don Nelson, assigns to Paideusis the right of first publication and educational and non-profit institutions a non-exclusive license to use this document for personal use and in courses of instruction provided that the article is used in full and this copyright statement is reproduced. Any other usage is probibited without the express permission of the author. 
educational discourse are many, of course, and while some of them have to do with the nature and difficulty of the philosophical work being done, the marginal position in the eyes of some is exacerbated by the place in society the Academy as a whole has today and the eroded and various foundations of the institution itself. If the value of what is done in the Academy as a whole is diminished, then claims by any one discipline to do better than others or better than ever before, can have short-term efficacy at best.

Philosophy of education suffers from afflictions coming from locations outside the Academy, but this paper will not look directly at those. There are many reasons why society regards empirical studies of education rather than conceptual ones as the basis of recommendations for action. Others have written of the fault of this too exclusive gaze. ${ }^{3}$ This paper will examine whether there are aspects of the conceptual foundations of the Academy itself that have affected the educational goals of the Academy through time and which now contribute to the devaluation of theory in general and conceptual studies in particular.

\section{The Glass Bead Game}

Much of the thinking in this piece results from a reading of Herman Hesse's novel Magister Ludi (The Glass Bead Game). Hesse's book is a novel, of course, and not a work of academic philosophy. As such it does not invite the kind of attention that one would give to a work of philosophy; in fact to regard it as a statement of ideas and argument only would be to miss the point of imaginative fiction. The advantage of responding to a work of fiction, as Peter Roberts $(2007,510)$ points out, is that it engages the reader on other levels than what might be called the strictly intellectual:

\footnotetext{
Novels, by taking us into the hearts and minds of characters, provide an especially helpful means through which to explore the nature and significance of ethical, epistemological and educational ideas for human lives....
}

Entering a fictional world, created through a complex novel, invites the reader to see issues through the eyes of the characters in the book, perhaps through the eyes of the author, and so through our own eyes seeing in ways that may not have been apparent before the experience of the book. Roberts (2008) points out that the main character of Magister Ludi, Joseph Knecht, represents someone who has fully realized "the significance of education in his further development as a human being." No small realization - and one that, Roberts goes on to argue, is based in an increasingly critical understanding of the Academy of which Knecht was such an important part. It is the critical view of the Academy in the novel seen through the experience of Knecht that provides opportunities for reflection on the modern Academy.

Much of Hesse's novel is set in the fictional province of Castalia in the twenty-third century, home to an Academy created by dedicated intellectuals after the Age of Wars or the Feuilleton Age. That age had been marked by the relegation of the pursuit of truth to a status subservient to the pursuit of power. Such intellectual studies as there were had been reduced to simple ideas for mass consumption, ideas to be read, discussed and discarded before the next moment of intellectual titillation was available. Either that or intellectuals served the state as apologists or propagandists. No wonder that the idea of truth came to be scoffed at and any notion of the beauty or nobility the pursuit of truth disappeared. In response, intellectuals intent on preserving what was valued of the "Classical age" stepped apart from the world and dedicated themselves to the care, analysis, understanding and preservation of the best of the past. Believing that no new creation would be possible in the debased state of the world, they sought through devotion and withdrawal, almost as secular monks, to preserve

\footnotetext{
${ }^{3}$ See for example Barrow (2000) and Shaker and Ruitenberg (2007).
} 
what had been the apogee of human culture.

The Age of Wars had left everyone looking for higher values and ideals than the greed and striving for power that had led to conflict and destruction. When the work of these secular monastics became known, their dedication, perseverance, and strong ethical example had the effect of demonstrating the higher devotion that was missing in the wider society. Their example gave them authority to assume key functions as educators, to be supported by the state in order to maintain their work, and to advance their own studies in isolation from the distractions and temptations of the world itself. The tradition of "The Order" was founded and supported by the state in return for the provision of teachers and a system where Culture and the Higher Life of the Mind were cultivated and preserved. The Board of Education and The Order supervised this Higher Education for selected students while others of lesser talent went to professional schools training students to do the work of the world.

The greatest achievement of this Order was the Glass Bead Game. This game was based on the tracing of connections and patterns found originally in music but later in all disciplines of the cultures studied and preserved by the Order. Games eventually came to be played annually in front of audiences that included some "worldly" representatives, as exhibitions of the intricacies of connection that unified the culture so carefully preserved.

The protagonist of the novel, Joseph Knecht, rises to the position of Master of the Glass Bead Game by following direction from the Board of Education and through giving himself entirely over to the Order. In this position, after years of consummate service including time "in the world" doing the Order's business, he foresees the end of the Game he has served and of the Order itself-both torn apart by historical forces beneath the notice of The Order immersed as its leaders are in the otherworldly concerns of the Higher Mind. He sees the world losing sight of the value of the Order's strict preservation of Higher Mind, being called to devote resources to other, more emergent events, while at the same time the Order is turning away from the world toward studies more and more esoteric, inaccessible, and driven by the concerns of Higher Consciousness. As a result of his Awakening, Knecht requests to leave his post, to return to the world as a teacher of the youngest minds, those least bound up in the dangerous dichotomy of cultures. When he is refused leave, he deserts his post to pursue his new purpose, and drowns in the icy cold of a mountain lake after following his one youthful student's plunge into the enthusiasm of a new day.

Magister Ludi is not the most encouraging of stories. Knecht is not a traditionally tragic figure, his best qualities being his ability to befriend and encourage others, his own dedication to service, and his moments of Awakening when he sees his world asking him to act in new ways. If he is heroic, it is not through hubris; rather, it is because of his faithful responses to the call of his vision of the danger that threatens his beloved Academy. A master of the techniques of meditative self-control, he responds to this call with a serenity that is far from the suffering of an Oedipus or a Lear.

It is Knecht's role in his Order and his ultimate apparent rejection of it that suggests parallels with the place and function of higher learning in our culture. The next section of this paper outlines some of these parallels and the questions that they pose about the future of our Academy. In addition, the response of the Educational Order itself to the world in the novel suggests interesting parallels and contrasts to the contemporary response of the Academy to the world in which we find ourselves.

\section{The Future of the Academy}

\section{On Knowing}

The great accomplishment of the Educational Order in Magister Ludi is the Glass Bead Game itself. It has grown from its origins in music to eventually incorporate all the higher knowledge of the Order in one form of symbolic expression. All that is discovered, preserved, and maintained finds expression in 
the language of the Game. Patterns and connections are presented in each game and made objects of veneration and meditation. In this way, the Game is at the same time a validation and an exhibition of all that purports to be higher and rational. The game connects and excludes. It connects the philosophy of history, for example, with its rational patterns and historical dialectic, while it excludes the particular with its focus on people and places at particular times, and the passions and needs that direct their actions. It displays what "makes sense" and excludes to a lesser realm all that is driven by circumstance or personality.

Peters and Hume (2003) have argued that the Glass Bead Game represents a Utopian vision of a specific kind of humanistic and rational knowledge. They refer to it as Platonic though it also might be called Cartesian: it represents the idea of a rationality that is all encompassing, that contains within it all that is worthwhile - whether that rationality is found in a world of forms or only in the mind. Hesse describes the place where it is found as the Higher Mind. It is certainly not a rationality that is circumscribed by culture or history. Whatever else it might do, the Game represents an "eternal" knowledge made public through the symbols of its performance-a knowledge cultivated through the disciplines of the Order. Knecht, as Master of the Game, worries that it will only remain vibrant as long as it can incorporate all that is discovered, and his fear is that it cannot incorporate the narrative of history in its specificity and materiality-the very events of the state that support the foundation on which the Game and the Castalian Academy are built.

In contrast, the modern Academy is increasingly based on multiple foundations of knowledge that are more noted for their differences than their relatedness. These many different ways of knowing are supported by social interests as diverse as multiculturalism, feminism, and political ideology. "Think tanks" have been established within and on the periphery of the Academy to represent the political Right and Left because of the idea that one side or the other dominates the Academy itself. The idea of truth, in any commonsense notion of the word, under the gaze of Postmodernism in its various forms, is variously complicated, and even consensus seems undesirable as it might reflect mere ideological agreement. Truths about education, whether metaphysical, theological, or epistemological grounds once supported them, seem gone-replaced by negotiated "bridges" built between often competing interests held by business, science and technology, and government (Peters and Hume 2003, p. 431). Where there is truth to be found, many would consider that the only way to find it would be through the scientific search for best practices. Consequently, the humanities are notably absent in this bridging of interests, and one must wonder where any distinctly educational concerns (should such things still exist) fit as well.

\section{Science versus Culture?}

One instance of conflict between multiple foundations of knowledge in the modern academy is that between science and humanities. Given canonical expression by C. P. Snow in 1959, this division still reverberates in the Academy. ${ }^{4}$ This is a significant difference from the academic world of Magister Ludi. In Hesse's novel, the culture of the intellectuals of Castalia was entirely that of the Traditional Culture of the Humanities. Science and technology in any modern form were not part of the Academy, devoted as it was to the preservation of Culture. It is unlikely that any of the Castalians would know the Second Law of Thermodynamics or other ideas that now are considered the scientific equivalent of the works of Shakespeare. Professional training, aside from the education of the elite school master, was left to the institutions of the world which provided the doctors, lawyers, economists, and so on required for the actual operation of society and the state. The Academy had little to do with this training.

This sharp contrast to the modern Academy suggests many tensions that can be found there. The tension between theory and practice within Faculties of Education has been mentioned above, and there are others, for example, between Empiricists and Philosophers or those seeing teaching as an art

${ }^{4}$ At least in England. See Melvyn Bragg (1999). 
rather than a technology. Unlike Castalia, there is no acknowledged central or unifying study. Different foundations are valued because of their diversity, but this can sometimes conceal an uneasy ceasefire sometimes threatened by competition for resources. It is not at all unusual to have competing schools of thought in this way in other disciplines: physicists come in experimental and theoretical varieties, and there are any number of schools of literary criticism. ${ }^{5}$

The challenge is that a diversity of answers can seem like no answer to someone needing to answer the question "But what do I do tomorrow?"- the common concern of many practicing educators. These divisions can easily be confusing to students (at least) and have lasting effects. They may contribute to the dismissal of the values of courses in educational philosophy and theory by practitioners (though methods courses sometimes fair no better). There is no a priori reason why philosophical thinking about education should not be important to those who teach or to those who make decisions about teachersand education-just as there is no a priori reason why a diversity of critical and precise thinking founded on conceptual, theoretical or empirical modes should not be valued. But when different approaches are seen as competing for truth on the one hand, or as denying the possibility of truth on the other, perhaps the confusion and judgments are more understandable.

Diversity of knowledge is not the challenge that Knecht faces in the novel. He is sent several times back into the world that supports the Castalian academy and so becomes aware of a threat to its existence. The world does not either understand or value the esoteric knowledge of Castalia as it once did. In a time of growing practical and political concerns, supporting The Order is losing priority. When Knecht brings this concern to the attention of the Order, their singular focus limits both their ability to conceive of the threat itself and their thinking about how to respond to it.

Within the modern academy, C. P. Snow argued that the traditional literary culture, in a way perhaps analogous to the esoteric order of the novel, did not know or value science. F. R. Leavis, as a representative of that literary culture responded with a vengeance. Now, perhaps, we can still ask: Without tradition, what holds the academy together? The quest for truth is challenged by competing foundations or contested as a possible quest at all. Acquiring knowledge, creating or discovering knowledge, and the contest to claim knowledge over other approaches has lead to the present balkanization of our academy. Without something like a singular idea of what an educated person might be, when that idea can no longer be the idea of having a breadth of knowledge in a single subject area, then it is not just the idea of a general or liberal education that loses its point. Why learn when there is nothing that can be known beyond the confines of a self-sustaining but ultimately illusory discipline? Why learn theory when one just has to learn to do? These sorts of questions easily multiply, and any high school teacher has heard his or her share: Why learn poetry, when one isn't going to be a poet? Why learn about classical architecture when one is just going to design houses? Why learn chemistry when one is just going to sell shoes? The converse questions also emerge: just recently a graduating high school student I taught asked somewhat guiltily, "Is it wrong to go to university not knowing exactly what I'm going to do?" The absence of a notion of an educated person as a good in itself has almost by default left education-as-career-training as the pre-eminent value of schooling. ${ }^{6}$

\section{Age of the Feuilleton}

Prior to the initial foundation of the Castalian Academy was the Age of the Feuilleton. A feuilleton was a journalistic article, often attached to the political or cultural sections of a newspaper. Hesse writes of this age that the feuilleton had taken over from all other kinds of cultural writing. Discussions of the Arts and Literature had been reduced to this level of popular consumption, with its implied need for

\footnotetext{
${ }^{5}$ For discussion of the effects of competing claims about truth in the academy see, for example, Mark North (2006) "Chastened, Not Stirred: The Secret Agents of Literature Departments Reap What They Sow."

6 The notion of knowledge as a means to the end that is employment has its own impacts on what counts as knowledge and students' attitudes to leaning. See Silvia M. Grinberg, "Education and the Tragedy of Culture."
} 
fresh stimulation and the making of links between the great and the mundane. It was this use of culture and literature for popular consumption and propaganda that resulted from putting intellectualism in service to popular culture on the one hand and political masters on the other. Q. D. Leavis had written in 1939 of the disappearance of magazines published for the educated general reader and how they were being replaced by specialist journals-if they were replaced at all. This suggests how the idea of the educated person had begun to diverge from that of the specialist, and even from the general public.

One way to describe the writing of the Age of the Feuilleton is to think of it in terms of the writer's purpose and his or her intended audience. The feuilletons were intended to inform, but more specifically to entertain or amuse, perhaps even to reinforce existing ideology. They were written for the common member of the reading public to fill in such moments of the day as could be devoted to reading. They needed to be "fun"- just as learning now is often supposed to be "fun."

The Castalian response to this age was to reinvigorate the most dedicated forms of scholarly writing, to focus on the intellectual domain of thought, the most logical presentation and so on. In short, the kind of standards for publication that today scholars would expect of the most prestigious, peer-reviewed journals - those in which publication counts the most towards prestige in the scholarly world. By focusing on writing only for other initiates, the Castalians created forums that provided the perfect environment for the distillation of thought down to concentrated formulae often expressed in dialects known only by these initiates. But they still had the glass bead game that, through its forms and performance, provided links which kept the esoterica of separate disciplines tied together.

Today's academy, seen as a postmodern institution, has no such unifying intellectual discipline, nor is there an educated population to whom it can appeal in so far as the products of the academy are credentialed and employable specialists. Within a small part of the academy, there is a movement to encourage writing about modern academic thought in a way that is accessible to a wider audience than single discipline or professional specialists. This movement writes in forms that vary from letters to the editor to books. Works of this type have been taken to be the beginnings of a "third culture" distinct from the two former contenders-though this culture seems to be restricted to writers in "the empirical world." 7 This small movement aside, the predominant form of publication within the academy is in peer reviewed and almost exclusively peer read journals. Does the specialization of disciplines demand only this form? Must anything written with other intent fall under the category of popularizing theory - that is reducing its complexity and depth for a less educated audience? It seems that the threat of the feuilleton and the structure of recognition in the academy necessarily separated readers and so the products of writers into two separate and in some ways isolated groups which are the social preconditions for the developments that Knecht feared in the novel.

\section{Service or Self}

In Knecht's final conversation with his superior, the President of the Order, he seeks to explain his awakening to the threats facing the Order and the moral imperative that he feels to act against all convention because of these threats. His duty was clear to him. This awakening was undeniable and completely in keeping with the past awakenings that had made him a perfect Castalian. Yet, in the President's eyes at least, instead of making Knecht Castalian, his most recent awakening was leading him to act in profoundly un-Castalian ways. It was exactly the kind of self-centred action that Castalian methods and institutions had been designed to shape and control. Where for Knecht it was the deepest kind of insight and call to action, for his peers in the Order it was madness.

But saying it was madness does not necessarily discount the validity of what Knecht was saying. One of Foucault's (1988) insights is that madness was once seen as a corrective revision of a dominant

\footnotetext{
7 "The third culture consists of those scientists and other thinkers in the empirical world who, through their work and expository writing, are taking the place of the traditional intellectual in rendering visible the deeper meanings of our lives, redefining who and what we are." (Taken from "The Third Culture" website.)
} 
discourse or self-contained and inescapably consistent way of thinking. Madness had the ability to open a window on other ways of thinking. The fool or the madman remind us that the necessities of thinking are constructed and maintained within a time and place. Foucault argues that in the modern age, however, madness became a medical condition that gave birth to a mistake, an unhealthy fixation powered by overwhelming emotions. The profoundly critical "unreason" of a Shakespearean Fool became the ramblings of someone too sick to see correctly. While Knecht certainly did not see himself as Fool, though he feared he would only appear foolish, his desire to leave The Order on his "absurd" quest looked like madness especially because it challenged basic presumptions upon which the order was based. Could understanding the world in its particularity offer something of intellectual importance? Madness!

The danger to the modern academy is that it find itself in the same position as The Order of the novel-so immersed in one way of thinking of its purpose and pursuits that other views are inconceivable.

\section{A Short and Inaccurate History of the Academy}

These reflections suggest that another fictional history might be useful — the imaginary history of our present Academy. In some ways, the present Academic endeavor is on as uneasy ground as was Hesse's imagined schools of the Age of Wars. In other ways, it is on the shaky ground that Knecht foresaw in increasing specialization leading to a general public that stops seeing the value of rarified experts. Or it has been moved to a new location that is very different from the old neighborhood, where professional training has replaced the idea of a general education. Some aspects of all these metaphorical descriptions apply. Our Academy has been built on the foundations of the old academy while at the same time undermining them in many ways.

Plato began the first academy in a garden in a grove of sacred olive trees that he inherited from his father. He built the structure of his academy on the metaphysical foundation of the world of forms and the belief that reason and geometry would provide access to this world where the ultimate models of truth, beauty, and justice resided. His students would leave as leaders who had clearer, better, and higher knowledge of truths that are otherwise obscured in the ordinary world of experience. In an ideal world, they would be kings. Reason suitably developed provided access to higher knowledge.

This foundation was altered by Augustine who saw this transcending reason as a gift given from God to allow access to His Kingdom and knowledge of Him. Theology bolstered metaphysics in supporting education. Priests needed to be educated to read the Word and those fully immersed in the religious life needed other instruction to lift them above this worldly plain.

With the Enlightenment, reason became a more human ability that allowed us to see through to the truth. Still, it was the cultivation of reason that provided places of learning with their foundation and justification. The Academy was a place where the cares and concerns of the world could be set aside and where reason was preserved and developed - in its graduates, at least. Thus, graduates, while most perhaps were destined to be religious leaders, were no longer exclusively destined for the clergy; they were generally deemed suitable for positions of leadership-perhaps as much by birth as by education.

But soon, reason was set free from metaphysics and theology. Its old scholastic subjects were left behind as relics of another age. The abstractions of geometry were replaced by discoveries in science based on systematic observation that allowed the useful shaping of the world through science and engineering. The old foundations of the Academy were threatened. The Academy responded. The solution was the incorporation of these new sciences in the Academy itself. As the theorists of this modernization might have put it, the Academy had to evolve to fill new niches in the knowledge environment.

It was hard to argue with the triumphs of modernity where economic prosperity and power 
followed, especially as those developments were often accompanied by expanding personal liberty. Yet modernity had, and has, its critics, and those critics weakened the grand narratives of modernity. The problems of progress (such as environmental damage, increasingly destructive wars, and economic inequality) did nothing to allay suspicion or reassure most people that the new products of the scientific Academy could be trusted. Expert knowledge was replaced by "common sense." And common sense was the last thing some of the emerging postmodernists wanted: it was the arbitrary and banal that passed for common sense; why defer to getting things done that needed doing? - Why "needed?" Why support old regimes of power?

The Postmodern critiques bring us to the present state of the Academy. The justifications that had supported the Academy have fragmented, and with them the foundations are shaken. Now some schools work at producing technicians needed to run complex businesses and societies, others work at preserving old traditions, while yet others work at overturning traditions and societies that themselves seem without foundation. Without a unifying metaphysic (or some would say the possibility of any "metaphysic"), a common faith, or confidence in the inevitability of progress, what is there to hold the Academy together besides its buildings?

There was an effort to support at least some of what had traditionally been taught as "forms of knowledge." 8 These were areas of study that in themselves were seen to have a kind of internal coherence and standards of right or wrong - and so to have an intrinsic worth. Unfortunately, it was difficult to identify many of these and their standards, particularly against a chorus that intoned any standards were arbitrary, empty, outcomes of tradition or impositions of power. News of this foundation-shaking conflict became widespread and the tolerance and respect of the world outside the Academy, for a long time somewhat condescending, became riddled with irony. As a result, the Academy was still looked on as a training ground for those seeking higher paying jobs, but its learning was seen more and more as arbitrary hoops that needed to be jumped through or negotiated around.

\section{Conclusion}

The fictional history of the last section connects with the final events of Hesse's novel. Knecht left the Order in the end because he awakened to the dangers threatening Castalia and his dedication to the Order demanded that he act. The existence of the dangers that the Order itself could not face, or even imagine, pushed Knecht to imagine a new kind of education that somehow connected the concerns of Castalia with the living moment of history in which its learning was unavoidably situated. Even though the people of the world and the Order of Castalia had become trapped in a kind of perpetual thesis and antithesis, locked in world views that made mutual comprehension impossible, Knecht's awakening convinced him that this could be changed, that his greatest service to Castalia would be to take steps into the world in search of some form of synthesis that could be contained in individuals. His death at the end of the book, even though it dramatizes his absolute commitment to his new task, leaves the question open as to what form such a synthesis could take.

What is tragic is that the epistemological and moral commitment to the Rule of the Order makes it impossible, or at least highly unlikely, that any leaders of the Order could conceive either of the dangers to their system or changes and responses that might be made to meet emerging conditions while, at the same time, the focus of the world on the increasingly pressing issues of politics and economics distance people from what appreciation of the academic work of the Order and the beauty of its Game that, as outsiders, they could have.

What are some of the consequences of the comparisons between the Modern Academy and the Order of Castalia in Hesse's novel? While I hope that the comparisons themselves have been fruitful,

\footnotetext{
${ }^{8}$ See Hirst 1973, for example.
} 
what follows is more speculation than the sort of conclusion after which one writes QED. The argument in this paper, depending as it does on comparisons between the imaginary Castalian Academy and our own, has suggested a number of oppositions and similarities. While these comparisons serve a purpose, by their binary nature they can do little to suggest a path to follow. The speculations that follow come from the comparisons developed above.

The multiple epistemologies and competing claims to knowledge have threatened the Academy's purpose as a provider of knowledge. Without our own Glass Bead Game, grand narrative, or other unifying structure, we empower alternate dialogues which may at the same time reduce credibility and spread confusion. We see the limits of knowledge everywhere and, as a consequence, leave action to those who just want to get things done or play whatever game there is to win. As knowledge is relativized to culture or intellectual discipline, claims to knowledge as truth are circumscribed. Knowing becomes important for what knowledge can do in practical applications, like making a car run or making students behave in class. Thus prestige and importance is attached to the sort of empiricist claims that say, "Do this action to achieve this result." In education, this takes the form of prescriptive best practice and the hope of pre-service teachers that they can just be told in straightforward ways how to teach. The corollary of this hope is the antipathy towards theory that is not prescriptive but descriptive, conceptual, or speculative.

Perhaps a less imaginary historical look at the science versus humanities discussion and the impact of certain postmodern ideas would reveal more of the impact on the foundations of the academy. That is, however, a work beyond the scope of this article. But it is clear that we are a long way from the kind of aesthetic interplay of ideas and meditation that made up the Glass Bead Game of Hesse's novel — which may not be a bad thing even though it does erode the traditional foundation of the academic endeavor. The traditional notion of an educated or cultured person comes heavily laden with sexist, classist, and Eurocentric baggage — and it is quite right that all that weight be acknowledged and critiqued. But after this critique, what remains of our conception of an educated person that could still give educational purpose to the academic system?

The absence of an educated public, or the importance of such a public being discounted, has meant that academic writing is almost exclusively aimed at an audience of academic peers. In this way writing that matters to the Academy, that pursues such knowledge as there is, furthers the divide between the potentially educated public and the Academy. Certainly, there are some matters that will only be understood by a specialized few, but should this be taken as a necessity or an ideal? Must the real work of thinking and research go on in specialized journals so that later it can be watered down for ordinary consumption? This way of looking at the matter may be more a habit of perception than a logical necessity. For me, there are more questions than answers here.

Knecht's final actions, seen as madness or betrayal by the Order he was seeking to serve, raise a final point. For Knecht, the dedication to the knowledge preserved and expressed in the Game of which he was master was inseparable from a set of virtues or dedications that guided his actions on the deepest level. It may be that as the idea of an educated person as knowledgeable becomes more contested and complex, there needs to be a focusing on the virtues, to use one form of words, that an educated person displays. ${ }^{9}$ While Plato used the idea of a well-ordered city to describe a well-educated individual, perhaps for us it is time to reverse that order and conceive of a well-ordered, thoughtful, and happy individual first. When we imagine the qualities and virtues of such a person, we can begin to imagine an Academy that might participate in educating such a person. That would be one way to describe a suitable goal, community, and foundation for the Academy. That conception could be the foundation for a new architecture. Without a clear conception of what educational virtues the Academy has to offer, we will continue to see the value of our institutions measured by the number of students in seats, examination scores, degrees conferred, average salary of graduates, or other arbitrary measures of

\footnotetext{
${ }^{9}$ See Megan Laverty, "Philosophy of Education: Overcoming the Theory-Practice Divide" for an example of how philosophy can contribute to the development and understanding of the values of pre-service teachers.
} 
success. Philosophy might, by taking on the challenge of describing an educated person for the times in which we live, save education from being co-opted by the values of the marketplace. In taking on this challenge, philosophers of education might also bring in their own discipline from the margins where some would place it.

\section{Acknowledgements}

An earlier version of this paper was presented at the GSCOPE 2007 conference at SFU on October 13, 2007 and benefited from the discussion that followed. It has since been rewritten in response to the useful comments of reviewers for this journal.

\section{References}

Barrow, R. (2000). The poverty of empirical research in education. Journal of Moral Education 29(3), 313321.

Bragg, M. (1999). Whose side are you on? Forty years after C.P. Snow delivered his 'Two Cultures' lecture, are science and the arts any closer to ending their intellectual war? London Observer, Review, 2 .

Entwistle, H. (2001). The relationship between educational theory and practice: A new look. In W. Hare \& J. Portelli (Eds.), Philosophy of education (pp. 19-29). Calgary: Detselig Enterprises.

Foucault, M. (1988). Madness and civilization: A history of insanity in the age of reason. New York: Vintage Books.

Grinberg, S.M. (2007). Education and the tragedy of culture: Pedagogical notes on the rational. In D. Vokey (Ed.), Philosophy of Education 2006 (pp. 142-149). Urbana-Champaign, IL: Philosophy of Education Society.

Hesse, H. (1970). Magister Ludi (R. and C. Winston, Trans.). Toronto,: Bantam. (Original work published 1943)

Hirst, P.H. (1973). Liberal education and the nature of knowledge. In R. S. Peters (Ed.), The Philosophy of Education (pp. 87-111). London: Oxford University Press.

Joram, Elana. (2007). Clashing epistemologies: Aspiring teachers', practicing teachers', and professors' beliefs about knowledge and research in education. Teaching and Teacher Education, 23, 123-135.

Leavis, Q.D. (1939). Fiction and the reading public. London: Chatto and Windus.

Laverty, M. (2006). Philosophy of education: Overcoming the theory-practice divide. Paideusis, 15(4), $31-44$.

North, M. (2006). Chastened, not stirred: The secret agents of literature departments reap what they sow. Telos: A Quarterly Journal of Critical Thought, 134, 118-139.

Peters, M., \& Humes, W. (2003). Educational futures: Utopias and heterotopias. Policy Futures in Education, 1(3), 428-439.

Roberts, P. (2007). Conscientisation in Castalia: A Freirean reading of Hermann Hesse's The Glass Bead Game. Studies in the Pbilosophy of Education, 26, 509-523.

Roberts, P. (2008). The dream of a journey to the East: Mystery, ritual and education in Hermann Hesse's penultimate novel. Paideusis, 17(1), pp. 45- 58.

Shaker, P., \& Ruitenberg, C.W. (2007). Scientifically-based research: The art of politics and the distortion of science. International Journal of Research and Method in Education, 30(2), 207-219.

Snow, C.P. (1998). The two cultures. Cambridge: Cambridge University Press.

The third culture. http://www.edge.org/3rd_culture/. 


\section{About the Author}

Don Nelson is a PhD candidate in the Philosophy of Education at Simon Fraser University and an experienced secondary school teacher of English, Literature and Writing in the Langley School District in British Columbia. He is currently working as a Faculty Associate in the Professional Development Program at Simon Fraser University. He can be contacted through email at dinelson@sfu.ca. 